\title{
Assessment of the abundance of actively respiring cells and dead cells within the total bacterioplankton of the Strait of Messina waters
}

\author{
G. Caruso ${ }^{1}$, G. Zappalà ${ }^{1}$, G. Maimone ${ }^{1}$, F. Azzaro ${ }^{1}$, \\ F. Raffa ${ }^{1}$ \& R. Caruso ${ }^{2}$ \\ ${ }^{1}$ Istituto per l'Ambiente Marino Costiero (IAMC), \\ National Research Council, Messina, Italy \\ ${ }^{2}$ Hospital Agency “G. Martino”, University of Messina, Messina, Italy
}

\begin{abstract}
In aquatic ecosystems, the determination of the different physiological states coexisting within the bacterial assemblage is of great significance, as it may provide information on the effective role played by the viable component in the ecological processes. In May 2007, during a ship survey of the Messina Strait, a highly hydrodynamic system, an investigation was undertaken to study the abundance and distribution of the actively respiring and dead components of the bacterioplankton community. A dual-labelling procedure was applied, using SyBR Green as a probe of the total bacterioplankton community, in combination with the viability stains cyanotetrazolium chloride (CTC) or propidium iodide (PI), selective markers of actively respiring or membrane-damaged bacterial cells, respectively. Surface water samples were analysed onboard by a flow cytometer (FCM) and FCM counts were compared to the microscopic ones, obtained with the epifluorescence (EPI) method further performed in the laboratory. The study also pointed out the feasibility of the FCM approach as a rapid tool allowing the identification of the viable component and its discrimination from the dead or damaged one, also providing quantitative estimates correlated significantly with microscopic counts.
\end{abstract}

Keywords: microorganisms, distribution, viability stains, living and dead cells, Strait of Messina. 


\section{Introduction}

Several studies on aquatic ecosystems have recognised the primary role played by microorganisms, both autotrophic and heterotrophic, in the ecological functioning of these environments [1]. Bacterioplankton represents a key component in the trophic dynamics and biogeochemical processes in marine environments [2]. Bacterial abundance is the result of a balance between the production of new bacterial biomass and its reduction due to top-down (by viral lysis or grazing pressure) or bottom-up (by nutrients) controls. Moreover, in nature allochthonous bacteria are also exposed to some adverse environmental factors, in response to which they may enter a "viable but nonculturable" survival state [3]. In ecological studies, the quantification of the bacterial fraction that is still alive is essential to correlate the abundance of active cells with the activity they effectively play within the biological processes [4]. New methodologies involving the use of fluorescent viability stains have been developed over the last decade to assess bacterial viability, that have shown a great potential in microbial ecology [5]. Most of the methods used rely on the ability of different fluorochromes to detect specific metabolic or functional activities, such as the respiratory activity for 5-cyano-2,3- ditolyl tetrazolium chloride (CTC) or cell membrane integrity, for propidium iodide (PI). Flow cytometry (FCM) technology has been recognised to offer a powerful tool for single cell analysis, providing in few seconds information on size, shape and fluorescence properties of millions of cells; it has multiple applications both in clinical and environmental research [6]. Besides FCM, the epifluorescence microscopy (EPI) is a simple method to study bacteria at individual cell level, according to their physiological and antigenic properties, with reduced time and labour costs [7]. Upwelling systems represent very productive ecosystems where the abundance of nutrients coming from the depth sustain massive phytoplankton growth; in these areas, however, little attention has been given to the heterotrophic component of the microbial community and especially to its physiological characterisation. Located at the centre of the Mediterranean, the Strait of Messina is a highly hydrodynamic site, where fast changes in the oceanographic conditions take place due to alternate exchange between the Tyrrhenian surface and the Ionian deep water masses, each with distinct termohaline properties. The peculiar hydrodynamic regime causes the upwelling of deep waters and mixing of Levantine Intermediate Waters (LIW) of Ionian origin with Tyrrhenian surface waters; this affects significantly the dynamics of biological components [8]. While the effect of hydrodynamism on the phytoplankton and other components of the trophic web has been widely investigated [9], knowledge of the distribution of bacterioplankton in this ecosystem and of their functional and metabolic role is still incomplete. Although recent studies have shown that the continuous mixing of various water masses along the Strait of Messina gives rise to short temporal and spatial variations in the distribution and activity profiles of the bacterioplankton community [10], till now no data exist on the composition of the bacterioplankton community with respect to its active and dead components. In 
this study, the abundance and distribution of the actively respiring and dead fraction of the total bacterioplankton in the Strait of Messina were investigated using FCM and EPI methods, in order to detect changes induced by opposite hydrological conditions on these biological components.

\section{Materials and methods}

The Strait of Messina connects the Tyrrhenian and the Ionian Seas, which have different physical, chemical and biological features, through a narrow and shallow area (about $0.3 \mathrm{Km}^{2}$ wide and $80 \mathrm{~m}$ deep) represented by the GanzirriPunta Pezzo section (called "sill"), giving rise to a funnel shaped geometry. Strong tidal currents originate from the different topographic conditions and the opposite phase tidal oscillations of the Tyrrhenian and the Ionian Seas; every 6 hours, a current flowing southwards from the Tyrrhenian to the Ionian Sea ("scendente" or high tide stream) alternates with another one flowing northwards from the Ionian to the Tyrrhenian Sea ("montante" or low tide stream). These periodical oscillations are separated by a brief slack water interval, during which turbulent tidal currents occur, with the generation of massive upwelling of cold water from the depths. The maximum intensity of tidal currents $(>3 \mathrm{~m} / \mathrm{sec})$ is recorded during spring tides, during sigizy lunar phases.

\subsection{Sampling}

On May 3, 2007 (sigizy phase), the area comprised between Capo Peloro (Sicily) and Reggio Calabria was tracked by the R/V "Luigi Sanzo" adopting a zig-zag strategy between the Calabrian and Sicilian coasts, in order to follow the wave of tide in the Strait according to the lagrangian method (Fig. 1).

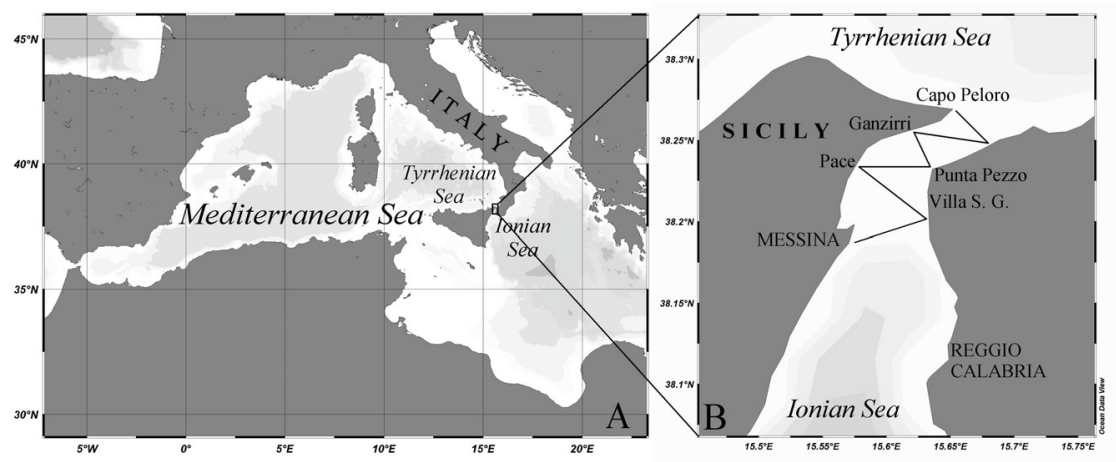

Figure 1: $\quad$ Study site (A) and sampling strategy (B).

Fifteen hydrological stations during each slack water period were sampled following the dynamic phases of high and low tides. In these quasi-stationary situations, the advective currents can be considered negligible and the variations 
in physical-chemical and biological parameters are more evident [8]. The current forecast from "Tide tables of the Istituto Idrografico della Marina, Genova" was used to individuate the low tide (after "montante") and high tide (after "scendente") slack water periods. Surface water samples for nutrient and bacterial determinations were taken using 10-liters Niskin bottles, from 8:30 a.m. to 11:55 p.m. ("montante") and from 2:00 p.m. to 3:47 p.m. ("scendente"), respectively.

\subsection{Physico-chemical measurements}

A SeaBird 19plus CTD probe was used to record conductivity, temperature and oxygen content at each station. Salinity and potential density $\left(\sigma_{t}\right)$ were calculated according to Fofonoff \& Millard's algorithms. Salinity values were calibrated through comparison with measurements made with an AutoSal Guildline induction salinometer Model 8004B. Samples for nutrient $\left(\mathrm{PO}_{4}, \mathrm{NO}_{3}\right)$ determinations were filtered through Whatman $\mathrm{GF} / \mathrm{F}$ filters and kept frozen $\left(-20^{\circ}\right.$ C). Analyses were performed according to Strickland and Parsons [11], using a Varian Cary 50 spectrophotometer.

\subsection{Bacterial counts: dual staining protocol}

Before FCM and EPI analysis, water sub-samples $(5 \mathrm{ml})$ were pre-filtered through a $100 \mu \mathrm{m}$-mesh size net to avoid clog the flow cytometer or the pores of the filtering membrane for epifluorescence microscopy. Aliquots $(2 \mathrm{ml})$ of the filtered sample were stained on board with a $10^{-4}$ dilution (vol/vol) of SYBR Green II (Molecular Probes, Eugene, OR, USA, final concentration, obtained from a $5 \mathrm{mg} \mathrm{ml} \mathrm{m}^{-1}$ stock solution prepared according to manufacturer's instructions), left to incubate in the dark for 10 minutes at room temperature. This is a nucleic acid staining probe for total bacterioplankton, fluorescing in the green wavelength range (maximum emission: $521 \mathrm{~nm}$ ) [4]. The SYBR Green stained sample was sub-divided into two replicates (1 $\mathrm{ml}$ each), which were separately treated with PI or CTC to assess the bacterial viability (as further described), and immediately analysed by FCM. The remaining volume was stored at $+5^{\circ} \mathrm{C}$ until laboratory treatment with the same viability stains and EPI analysis, performed within 2 hours of sampling.

To detect the fraction of non-viable cells, the sub-sample was incubated for 5 minutes in the dark at room temperature with PI (Sigma-Aldrich, St. Louis, MO, USA; final concentration: $0.01 \mu \mathrm{g} \mathrm{l}^{-1}$ ); this exclusion stain is able to penetrate cells with damaged or compromised membranes only (PI+ cells) and fluoresces in the red wavelength (peak value: $617-623 \mathrm{~nm}$ ) [12]. To detect the fraction of actively respiring cells, the sub-sample was supplemented with a $5 \mathrm{mmol}^{-1}$ solution of CTC (final concentration; Polyscience. Warrington. Pa), freshly prepared from the stock solution prepared according to manufacturers' instructions. CTC is a redox stain that in presence of oxygen is converted by electron transport system into formazan, which accumulates as red fluorescing granules within active respiring cells (CTC+ cells) [13]. 


\subsubsection{Sample analysis by FCM method}

In this study, an Apogee 40 (Apogee Flow Systems, Hemel Hempstead, Hertfordshire, UK) flow cytometer was used. This instrument uses epiillumination; this characteristic increases its sensitivity, allowing one to detect low size particles like bacteria. It is designed to work on board without sensible alterations in the alignment of the optical system and is equipped with a $50 \mathrm{~W}$ mercury arc lamp. All the parameters were collected as logarithmic signals. Green fluorescence was collected in the FL1 channel (515-545 nm band pass filter, specific for SYBR Green); red fluorescence was collected in the FL3 channel (650-690 nm band pass filter, specific for PI and CTC). Cells were enumerated during a fixed time ( 5 minutes) at a flow rate of $40 \mu$ minute $^{-1}$; a minimum of 5000 events was counted for each sample.

\subsubsection{Sample analysis by EPI method}

For EPI procedure, the samples treated with PI or CTC were filtered through Nuclepore black ( $25-\mathrm{mm}$ diameter, $0.22 \mu \mathrm{m}$ pore size) polycarbonate filters; the filter was further mounted on a glass slide using a drop of Immersoil $158 \mathrm{~F}$ (Zeiss). Counts were performed on at least 20 microscopic fields with a Zeiss Axioplan 2 epifluorescence microscope (Carl Zeiss Vision $\mathrm{GmbH}$, Munchen, Germany) coupled with an image analysis system, equipped with a $100 \mathrm{~W}$ mercury lamp and specific filter sets (blue light: BP 450-490, FT 510 and LP 520; green light: BP 510-560, FT 580 and LP 590). Under blue light excitation, SYBR Green + cells fluoresced in brilliant green, while under green light, PI+ and CTC+ cells were viewed as red fluorescing cells or intracellular granules, respectively. Observations were performed using a Neofluar objective at a 1000X magnification under immersion oil; counts were expressed as the mean value of cells observed per $\mathrm{ml}$ of sample (cells $\mathrm{ml}^{-1}$ ).

\section{Results}

\subsection{Physico-chemical measurements}

Temperature values ranged from 15.30 to $18.44^{\circ} \mathrm{C}$ and from 15.83 to $18.31^{\circ} \mathrm{C}$ during high tide and low tide slack waters, respectively. Salinity values ranged from 37.41 to 38.17 and from 37.38 to 37.98 during the same conditions. During low tide slack waters, the maximum nitrate concentrations were found near the Calabrian coasts $(1.41 \mu \mathrm{M})$ and were associated with the maximum salinity (37.98) and the minimum temperature $\left(15.83^{\circ} \mathrm{C}\right)$. Lower nitrate concentrations $(<0.3 \mu \mathrm{M})$, close to undetectable values and associated with the minimum salinity (37.38), were measured along the Sicilian coast. During high tide slack waters, the nitrate concentration increased near the Messina harbour, where a maximum $\mathrm{NO}_{3}$ value of $2.10 \mu \mathrm{M}$ was recorded, together with the maximum of salinity (38.17) and the minimum temperature $\left(15.30^{\circ} \mathrm{C}\right)$. During the low water slack tide maximum orthophosphate values $(0.42 \mu \mathrm{M})$ were measured together with the maximum nitrate values; during the high water slack tide, maximum $\mathrm{PO}_{4}$ values $(0.46 \mu \mathrm{M})$ were found in the western part of the central zone. 


\subsection{FCM counts}

Bacterial counts obtained by FCM are reported in Figs. 2.
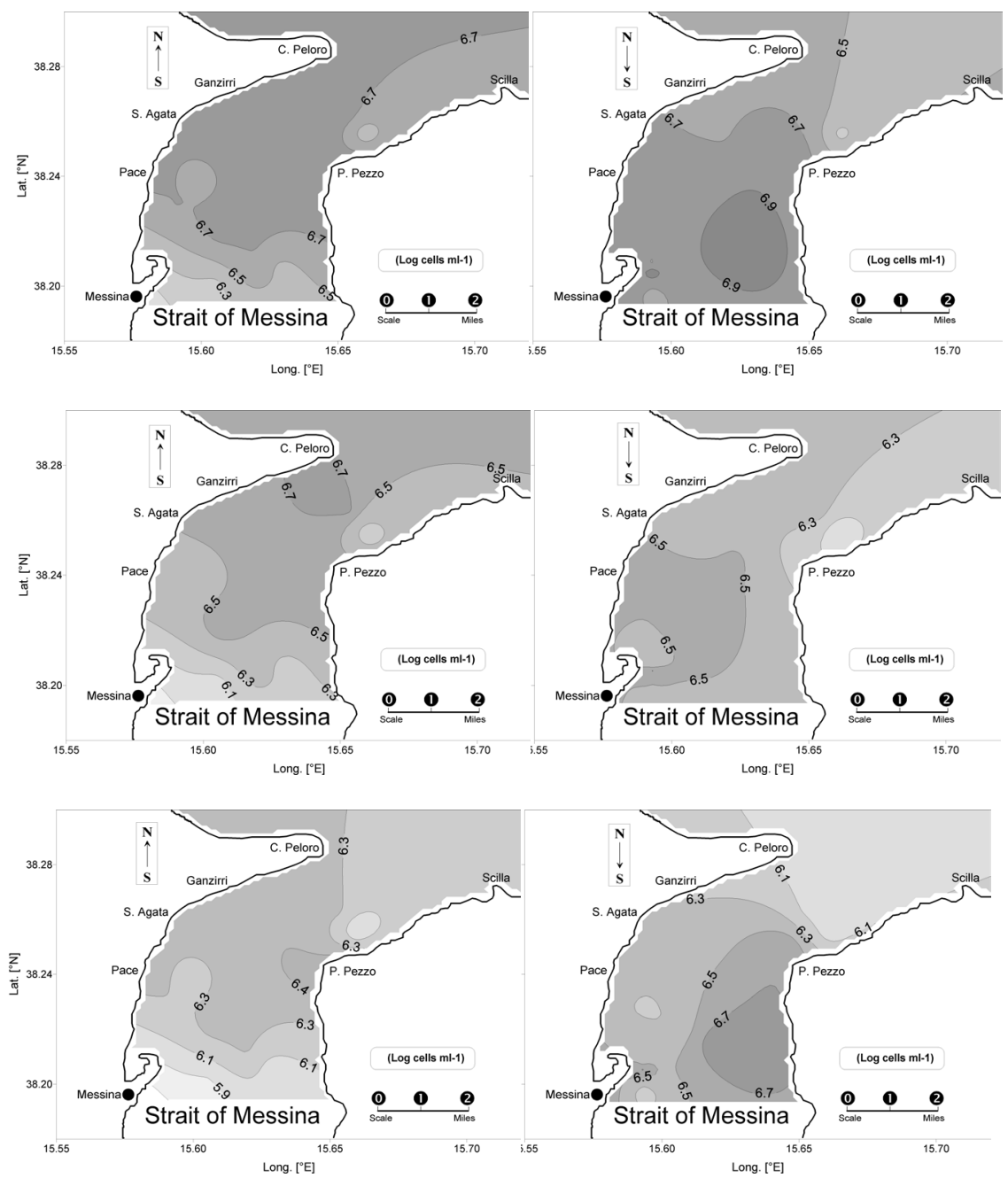

Figure 2: $\quad$ FCM bacterial counts (in log cells $\mathrm{ml}^{-1}$ ) obtained during low (left) and high tide (right) slack waters: upper, total bacterioplankton; intermediate, actively respiring $(\mathrm{CTC}+)$ cells; down, dead $(\mathrm{PI}+)$ cells.

During low tide slack water, the average value of total bacterioplankton was $4.71 \times 10^{6} \pm 2.63 \times 10^{6}$ cells $\mathrm{ml}^{-1}$. Values ranged from a minimum of $8.22 \times 10^{5}$ cells $\mathrm{ml}^{-1}$ (Messina harbour) to a maximum of $1.09 \times 10^{7}$ cells $\mathrm{ml}^{-1}$ (centre of the Strait). CTC+ bacteria ranged from $4.98 \times 10^{5}$ to $7.48 \times 10^{6}$ cells $\mathrm{ml}^{-1}$, recorded at Messina 
harbour and at Cape Peloro, respectively; these values represented on average the $59.21 \%$ of total bacterioplankton. PI+ cell counts varied between $3.09 \times 10^{5}$ (Messina harbour) and $3.92 \times 10^{6}$ cells $\mathrm{ml}^{-1}$ (Punta Pezzo); they represented on average $38.48 \%$ of total bacterial counts. Contour plots showed a similar distribution for total bacterioplankton, $\mathrm{CTC}+$ and $\mathrm{PI}+$ bacteria with an increasing gradient of cell abundance moving northward. The highest values of total bacteria were detected in the central area between S. Agata - Cape Peloro (Sicilian side) and Punta Pezzo (Calabrian side); actively respiring cells prevailed in front of Cape Peloro, dead cells on the opposite side (Punta Pezzo).

During high tide slack water, the average value of total bacterioplankton was $6.11 \times 10^{6} \pm 2.50 \times 10^{6}$ cells ml ${ }^{-1}$. A minimum of $1.75 \times 10^{6} \mathrm{cells} \mathrm{ml}^{-1}$ was recorded between Punta Pezzo and Scilla, while a maximum of $1.11 \times 10^{7}$ cells $\mathrm{ml}^{-1}$ was found south to Punta Pezzo. CTC+ bacteria ranged from $8.03 \times 10^{5}$, (between Punta Pezzo and Scilla), to $5.48 \times 10^{6}$ cells $\mathrm{ml}^{-1}$, (central area of the Strait); they represented on average $50.11 \%$ of total bacterioplankton. PI+ cells were comprised between $9.32 \times 10^{5}$ and $6.75 \times 10^{6}$ cells $\mathrm{ml}^{-1}$; they represented on average $48.24 \%$ of total bacterial counts. Total and dead bacterioplankton appeared to be concentrated along the Calabrian side, in front of Punta Pezzo, whereas $\mathrm{CTC}+$ cells prevailed along the Sicilian coasts.

\subsection{EPI counts}

Bacterial counts obtained by EPI are reported in Figs. 3.

During low tide slack water, the average value of total bacterioplankton was $2.98 \times 10^{4} \pm 1.09 \times 10^{4}$ cells $\mathrm{ml}^{-1}$. Values ranged from a minimum of $1.26 \times 10^{4}$ (Messina harbour) to a maximum of $5.48 \times 10^{4}$ cells ml $^{-1}$ (Strait centre). CTC+ bacteria ranged from $7.40 \times 10^{3}$, (Messina harbour), to $2.94 \times 10^{4}$ cells ml ${ }^{-1}$, (Cape Peloro); on average, they accounted for $57.57 \%$ of total bacterioplankton. PI+

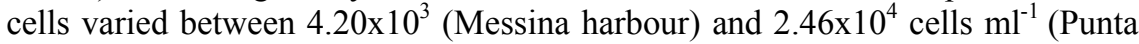
Pezzo); they represented on average $39.99 \%$ of total bacterial counts. Spatial distribution of total bacterioplankton, actively respiring and dead cells found by EPI method reflected that depicted by FCM, with the highest densities of total bacteria in the area S. Agata - Cape Peloro and Punta Pezzo. Actively respiring cells showed a peak along the Sicilian side, in correspondence of Cape Peloro, whereas dead cells were more abundant in front of Punta Pezzo.

During high tide slack water, the averaged value of total bacterioplankton was $3.41 \times 10^{4} \pm 1.0 \times 10^{4}$ cells ml ${ }^{-1}$. While a minimum of $1.85 \times 10^{4}$ cells ml ${ }^{-1}$ occurred

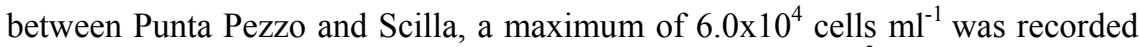
south to Punta Pezzo. CTC + bacteria ranged from $8.90 \times 10^{3}$ (Punta Pezzo), to $2.80 \times 10^{4}$ cells ml ${ }^{-1}$ (offshore Pace); they represented on average $45.93 \%$ of total counts. PI+ cells varied from $7.98 \times 10^{3}$ (between Punta Pezzo and Scilla) to $3.08 \times 10^{4}$ cells ml $^{-1}$ (offshore and south to Punta Pezzo), representing on average $51.59 \%$ of total bacterial counts. Bacterial densities measured by EPI displayed a spatial distribution similar to those found by FCM, with total and dead bacterioplankton concentrated in the central area of the Strait and along the Calabrian coast. 


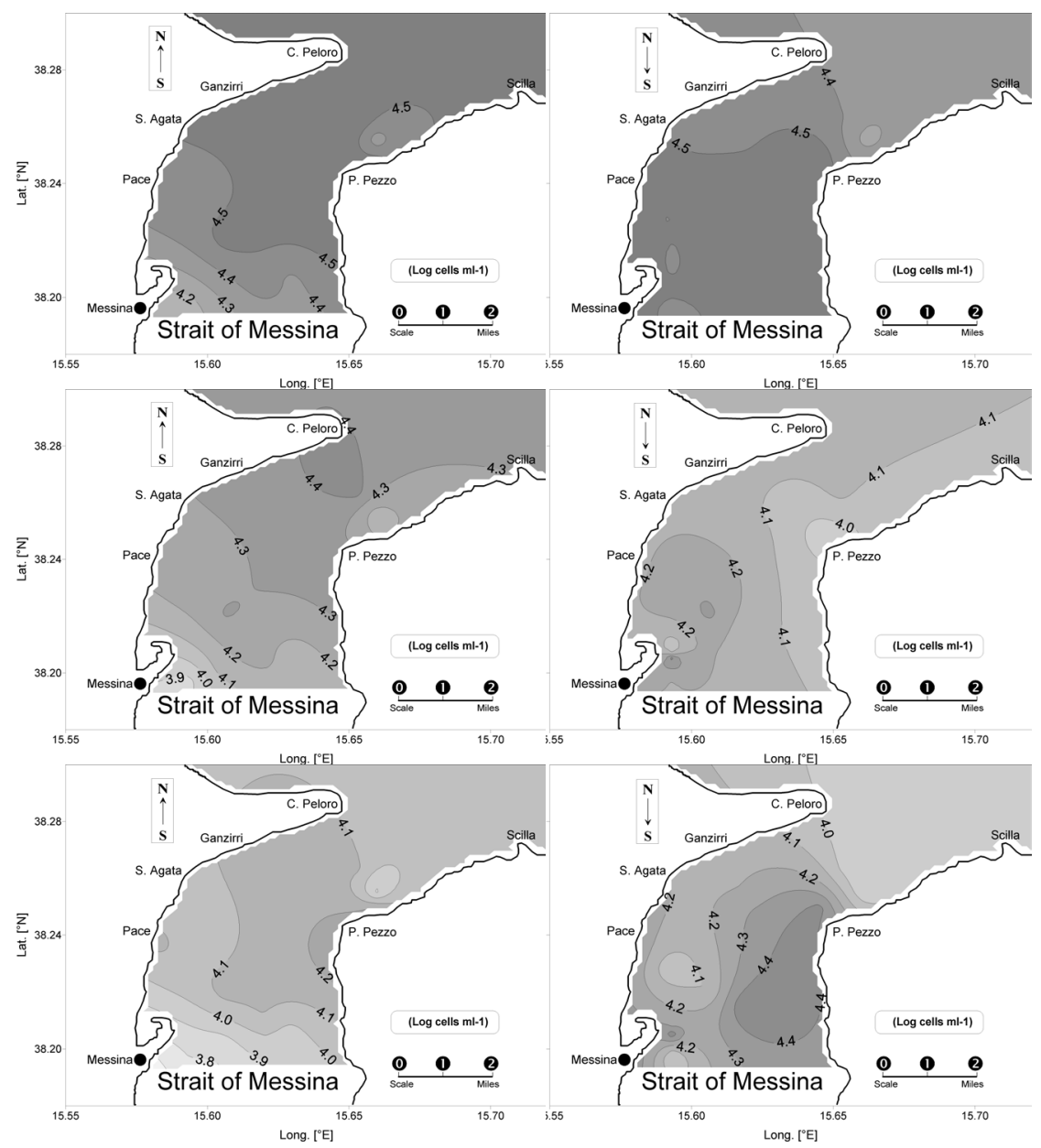

Figure 3: EPI bacterial counts (in log cells $\mathrm{ml}^{-1}$ ) obtained during low (left) and high tide (right) slack waters: upper, total bacterioplankton; intermediate, actively respiring $(\mathrm{CTC}+)$ cells; down, dead $(\mathrm{PI}+)$ cells .

\subsection{Comparisons between various methods and hydrological conditions}

The comparison between cell concentrations estimated by the FCM and EPI methods pointed out that FCM counts were two orders of magnitude higher than EPI counts, although Pearson correlation coefficients $r$ between FCM and EPI counts were statistically significant (low tide: $0.985 ; 0.947 ; 0.971$; high tide: $0.971,0.867 ; 0.967$ for total bacterioplankton, CTC and PI+ cells, respectively). Concerning the effect of different hydrological conditions, the high tide slack water condition, fed by Tyrrhenian waters, was characterised by the highest total bacterioplankton values; this bacterial assemblage, however, was dominated by dead or damaged cells, as suggested by high PI+ cell numbers. 


\section{Discussion}

The peculiar distribution found in the Messina Strait waters reflected the prevailing hydrodynamic condition; the "montante" stream moved northward the bacterial loading, concentrating total, both active and dead bacteria, in the northern sector of the Strait during the low tide slack water. In this condition, total, dead and active bacteria correlated positively with temperature and negatively with salinity; the opposite finding was observed during high tide. During the "scendente" stream, the Tyrrhenian stream moving southwards shifted and concentrated along the Calabrian side the highest numbers of total bacteria, within which a great percentage was found to have compromised cell membranes. This spatial distribution confirmed the influence of Tyrrhenian waters, characterised by high bacterial abundance, over the Calabrian coasts, in agreement with previous studies [9]. Conversely, the prevalence of cells with active metabolism along the Sicilian side probably depended on the increased nutrient concentrations due to upwelling that support the maintenance of bacterial metabolism, as suggested by the positive relationship of total and CTC + bacteria with salinity $(\mathrm{r}=0.495,0.439$, respectively) and nitrates values $(\mathrm{r}=$ $0.456,0.408$, respectively). Nevertheless, a direct relationship between the distribution patterns of total bacterioplankton and nutrients was not always found, confirming that bacterial dynamics, unlike to phytoplankton, do not strictly depend on nutrient availability only, but follow more complex patterns.

The FCM and EPI methods used in this study are cheap and rapid tools to detect different physiological states within the bacterial community, existing in natural seawater, which is not uniformly living and active [14]. Bacterial distributions depicted by the two methods were similar for spatial patterns, although FCM counts exceeded EPI ones by two orders of magnitude. This finding agrees with the consideration that FCM readings are not affected by operator's subjectivity and refer to high cell numbers. Moreover, membrane integrity or metabolic activity are only two different ways to detect bacterial viability in natural marine samples; in fact, the sum of the relative percentages of $\mathrm{CTC}+$ and $\mathrm{PI}+$ cells did not reach $100 \%$ of the total bacterioplankton, confirming the presence of a fraction of bacteria showing living attributes different from those determined in the present research. Although based on a limited data set, this study provides information on bacterial viability in Messina Strait waters and may elucidate current comprehension of the actual turnover rates of bacterial assemblage $[1,14]$; the percentage of actively respiring bacteria found in the Strait was in agreement with other coastal areas. In ecosystems like Messina Strait the use of FCM approach proved to be a simple and rapid methodology for the study of short term variations in the abundance and composition of bacterioplankton.

\section{Acknowledgement}

The authors thank A. Marini who helped with the analyses. 


\section{References}

[1] Cole, J.J., Aquatic microbiology for ecosystem scientists: new and recycled paradigms in ecological microbiology. Ecosystems, 2, pp. 215-225, 1999.

[2] Azam, F., Fenchel, T., Field, J.G., Gray, J. S., Meyer-Reil, L.A., \& Thingstad, F., The ecological role of water-column microbes in the sea. Marine Ecology Progress Series, 10, pp. 257-263, 1983.

[3] Rozen, Y. , \& Belkin, S., Survival of enteric bacteria in seawater. FEMS Microbiology Reviews, 725, pp. 1-17, 2001.

[4] Grégori, G., Citterio, S., Ghiani, A., Labra, M., Sgorbati, S., Brown, S., \& Denis, M., Resolution of viable and membrane-compromised bacteria in freshwater and marine waters based on analytical flow cytometry and nucleic acid double staining. Applied and Environmental Microbiology, 67, pp. 4662-4670, 2001.

[5] Joux, F., \& Lebaron, P., Use of fluorescent probes to assess physiological functions of bacteria at single-cell level. Microbes and Infection, 2, 15231535, 2000.

[6] Davey, H.M., \& Kell, D.B., Flow cytometry and cell sorting of heterogeneous microbial populations: the importance of single-cell analyses. Microbiological Reviews, 60, pp. 641-696, 1996.

[7] Caruso, G., Mancuso, M., \& Crisafi, E., Combined fluorescent antibody assay and viability staining for the assessment of the physiological states of Escherichia coli in seawaters. Journal of Applied Microbiology, 95, pp. 225-233, 2003.

[8] Azzaro, F., Decembrini, F., Raffa, F., \& Crisafi, E., Seasonal variability of phytoplankton fluorescence in relation to the Straits of Messina (Sicily) tidal upwelling. Ocean Science, 3, pp. 451-460, 2007.

[9] De Domenico, E., Cortese, G., Pulicanò, G., Chemical characteristics of waters in the Straits of Messina. Proc. Int. Symposium The Strait of Messina Ecosystem, eds. L. Gugliemo, A. Manganaro, \& E. De Domenico, Messina, pp. 31-41, 1995.

[10] Caruso, G., Azzaro, F., Galletta, M., Raffa, F., \& Decembrini, F., Microbial enzyme activities in the upwelling system of Messina Straits: dynamics and biogeochemical considerations. Mediterranean Conference on Chemistry of Aquatic Systems, Reggio Calabria, September 4-8, 2004, P9, 2004.

[11] Strickland, J.F.H., \& Parsons, T.R., A practical handbook of seawater analysis. Bull. Fish. Res. Bd. Can. 167, 1972.

[12] Sgorbati, S., Barbesti, S., Citterio, S., Bestetti, G., \& De Vecchi, R., Characterization of number, DNA content, viability and cell size of bacteria from natural environments using DAPI PI dual staining and flow cytometry. Minerva Biotechnologica, 8, pp. 9-15, 1996.

[13] Rodriguez, G.G., Phipps, D., Ishiguro, K., \& Ridhway, H.F., Use of a fluorescent redox probe for direct visualization of actively respiring bacteria. Applied and Environmental Microbiology, 58, pp. 1801-1808, 1992.

[14] Smith, E.M., \& del Giorgio, P.A., Low fractions of active bacteria in natural aquatic communities. Aquatic Microbial Ecology, 31, pp. 203-208, 2003. 